\title{
Sustainable Supply Chain Management and Organizational Performance: The Intermediary Role of Competitive Advantage
}

\author{
Charles Baah ${ }^{1} \&$ Zhihong Jin ${ }^{1}$ \\ ${ }^{1}$ Transportation Engineering College, Dalian Maritime University, Dalian, China \\ Correspondence: Charles Baah, Transportation Engineering College, Dalian Maritime University, Dalian, China. \\ E-mail: charlieba3@gmail.com
}

Received: February 27, 2019

Accepted: March 25, 2019 Online Published: May 10, 2019

doi:10.5539/jms.v9n1p119

URL: https://doi.org/10.5539/jms.v9n1p119

\begin{abstract}
Sustainability issues have been on the rise due to negative impacts of organizational practices on the environment. The logistics sector has been known as a major contributor in polluting and consuming enormous amount of resources. This study therefore aims to provide insight into how sustainable supply chain management (SSCM) influences performance of organizations operating in the logistics sector. This study went further to focus on the intermediary function of competitive advantage in the SSCM and organizational performance relationship. Questionnaires were distributed to solicit information from 190 logistics managers. Data were analysed using partial least square method of structural equation modelling. Analysis of the data indicates that SSCM significantly and positively influence competitive advantage and organizational performance. In addition, competitive advantage also proved to significantly influence organizational performance. Competitive advantage indirectly has a significant impact on the SSCM and organizational performance relationship. The findings of the study provide key information to managers and academics in understanding the essence of integrating sustainability in supply chain management (SCM) and how the integration influences organizational performance in the current business and industrial setting.
\end{abstract}

Keywords: sustainable supply chain management (SSCM), supply chain management (SCM), competitive advantage and organizational performance

\section{Introduction}

Rising issues such as global warming, energy crisis, ozone layer depletion among others have warranted or brought attention to the topic of sustainability in every facet of human existence. This concept has fully been viewed from the business perspective because of the enormous contributions documented from industrial activities. Although environmental issues started before the 1990s, major streams of sustainable research specific to the SCM discipline started in mid-1990s (Seuring \& Muller, 2008). The acceptance of social and other issues related to the environment evolved from what was referred to as "standalone" by Craig and Easton (2011) to the concept we currently refer to as sustainability. Sustainability issues arising from this current business environment have warranted organizations to consider sustainable practices in their goals and policies. There have been various definitions concerning sustainability (Craig \& Easton, 2011). According to WCED (1987), sustainability is utilizing resources to meet current or present generation's needs without endangering future generation. This definition although widely accepted does not really convey or address key topics in this current industrial environment making it quite open and obscure as supported by Ahi and Searcy (2013), hence, it is demanding and tough to incorporate this concept into supply chain operations. From the perspective of Elkington (1998), growth of sustainability theory needed to be considered from a triple bottom line comprising; integration of environmental, social and economic performances. Thus, Elkington (1998) signified that managers must promote operational activities that achieve economic objectives and achieve both social and environmental goals simultaneously. According to Carter and Rodgers (2008) the above opinion by Elkington (1998) suggests that considering and undertaking sustainable practices cannot be categorised as optional but compulsory for organizations.

Extant literature proves the ongoing debate regarding the adoption of sustainability in the business context (Ahi \& Searcy, 2008). Despite the ongoing debate, the rapid rise of sustainable issues has caused the intervention of international bodies, governments and other stakeholders thereby forcing organizations to consider how to 
incorporate environmental and social friendliness into their goals and policies so as to have minimal environmental impacts. Gao and Bansal (2013) agree that this has made organizations scrutinize their operational lines to reduce or eliminate negative or harmful processes, thus, creating resilient organizations that are likely to operate in environmentally friendly business environment. According to Gao and Bansal (2013) business sustainability is the ability to create a resilient organization through integrated economic, social and environmental systems. This implies that business sustainability promotes resilience and promotes a healthy environment. Organizations' decision to consider sustainability into their business operations affects every phase of their supply chain and enormously affects performance as well. Some scholars (Cheng et al., 2008; Robinson $\&$ Wilcox, 2008) argue that adopting sustainability especially from the environmental point of view requires huge investments that has the tendencies of depleting an organization's competitive edge especially if these investments are not recouped within an early period. Some other scholars (Miles \& Covin, 2000; Roslender \& Hart, 2002) also are of the view that incorporating environmental sustainability strategies gives an organization a competitive benefit, thus, making it a proceeding debate. For instance, past studies show that green product and/or green process innovations are positively related with achieving competitive advantage (Bhinge et al., 2015; Sharma \& Vredenburg, 1998). Furthermore, farsighted environmental strategy involves the execution of strategic procedures like the research and creation of environmental friendly products and recycling systems (Moser, 2015). There is therefore the necessity to add to existing literature in providing a link between SSCM and competitive advantage.

Organizational performance emphasizes how organizations attain its goals whether it being market oriented or financially oriented (Yamin et al., 1999). Financial measures over the years, have been used mostly for benchmarking organizations and assessing an organization's behaviour over time (Holmberg, 2000). Every phase of an organization, including SCM should eventually lead to an improvement in organizational performance. Significant literature have captured performance of firms and enterprises using financial and market criteria. These criteria include return on investment, market share, profit margin on sales, increase of return on investment, increase in sales, increment in market share, and general competitive position (Holmberg, 2000). In this study, organizational performance was measure using the above financial and market criteria. The diverse views by scholars have inspired an increase in studies all seeking to link sustainability to firm performance since most organizations are still thinking through how to integrate sustainable practices internally and also into their supply chains.

Therefore, it is prudent to study the impact of sustainability specifically in relation to SCM on organizational performance also taking note of how it affects competitive advantage and the intermediary function of competitive advantage in the specified relationship especially in the Ghanaian setting. Several studies on SSCM and performance were undertaken in developed countries and less research in developing countries (Zailani et al., 2012). A sample from Ghana, a developing country can contribute in showing SSCM results in a worldwide context.

\section{Literature Review}

\subsection{Integration of Sustainability and SCM}

Sustainability has been referred to employing the triple bottom line that is social, environmental, and economic responsibilities (Elkington, 1998). Now, the integration of sustainability and SCM has over the years been highly debated upon (Wang et al., 2017). This is due to different authors emphasizing different dimensions of sustainability and SCM. SCM has been defined by several scholars; according to Lambert et al. (1998), it is bringing together core business processes from end-user through direct suppliers that deliver information, products and services which create value addition for diverse stakeholders. In addition, Mentzer et al. (2001) also view it as a structured, well-planned integration of the conventional business tasks and the strategies across these business tasks within a peculiar company spanning across business units in the supply chain, with the main aim of enhancing the outputs of that single company and its supply chain. Stock and Boyer (2009), also defined it as the procedure of controlling a network of connections within a firm as well as between inter-dependent organizations and business units made up of raw material suppliers, procurement, production facilities, logistics, marketing, and affiliated systems which boost the reverse and forward stream of materials, services, finances and information from the main producer to end user with the benefits of creating value, increasing profitability by employing efficient systems, and achieving customer contentment. From the above definitions of SCM, it can be deduced that flow of materials and services, coordination of supply chain partners and information sharing make up the basis of the concept. According to Ahi and Searcy (2013), the following are some of the key characteristics of SCM; flow oriented, coordination based, stakeholder focused, relationship based, value and efficiency oriented, and finally performance focused. Now the key issue that scholars are trying to address is considering how to bring together the triple bottom line of sustainability and the above listed core aspects of SCM. 
According to Pagell and Gobeli (2009), SSCM can be referred as an organization's plans and practices that combine environmental and social issues into SCM so to enhance the organization's environmental and social outcomes and those of its direct and indirect suppliers and customers without jeopardizing overall performance. Form this definition, it can be ascertained that those core aspects of SCM needs to be implemented with intention to minimize environmental and socials issues in the supply chain. Thus, supply chain partners need to be fully monitored and evaluated if this is to be achieved, hence, making environmental and social evaluation very key components of SSCM. Carter and Rodgers (2008) also defined SSCM as a well-structured, transparent combination and attainment of an organization's social, environmental, and economic objectives in the planned coordination of key cross-organizational business processes for facilitating long-term economic outcomes of that peculiar company and its supply chains. Although, this definition was keenly based on the triple bottom line concept both of the above definitions signify that it is essential to consider both environmental and social components of sustainability in supply chain activities because according to Wang et al. (2017), organizations improve their internal processes by engaging in such practices. This study considers SSCM mainly from the environmental and economic perspectives.

\subsection{SSCM Practices}

Having highlighted on both sustainability and SCM, it is important to provide a theoretical understanding of the key activities or practices involved in this concept in a way to help make operational the SSCM concept. Different scholars have studied and highlighted SSCM practices to include sustainable procurement, supplier partnerships, information sharing, sustainable distribution, sustainable packaging, reverse logistics, etc. for different purposes (Svensson, 2007; Pagell \& Wu, 2009). According to Beske et al. (2014), SSCM practices consist of strategic orientation, supply chain continuity and collaboration, risk management and proactivity for sustainability. Esfahbodi et al. (2016), also highlighted SSCM practices from sustainable production, sustainable design, sustainable distribution and investment recovery perspectives. Thus, from the above it is evident that SSCM practices adopted by scholars are mostly influenced by the purpose of their studies. This has added to the evolving nature of SSCM practices. In this study, SSCM is described from the viewpoint of three core components of SCM as highlighted by Stock and Boyer (2009). According to Stock and Boyer (2009), these core components include flow of materials, supplier partnership and coordination, and information sharing. This study incorporates sustainability into these components by viewing flow of materials from the sustainable purchasing perspective (Gil et al., 2001), while considering supplier partnership and coordination from sustainable supplier partnerships (Green et al., 2012) and finally, information sharing from green information sharing perspective (Weeratunge \& Herath, 2017). These components were adapted for this study because largely they capture the essence of SSCM (Stock \& Boyer, 2009). According Green et al. (2012), it is good to examine the individual SSCM practices on performance but it is better to examine the total effect by considering the composite of SSCM practices on organizational performance. Relying on this suggestion, this study examined SSCM as a composite, which is reflected by sustainable purchasing, sustainable supplier partnerships and green information sharing. Each of the core SSCM components considered in this study is briefly introduced as follows:

\subsubsection{Sustainable Purchasing}

Sustainable purchasing has been uniquely defined by several scholars (Zsidisin \& Siferd, 2001; Carter et al., 2000), but primarily it deals with scrutinizing supplier sources and selecting from sources that are environmentally oriented, thus, purchasing materials that meet environmental requirements and regulations (Carter, 2005). Gil et al. (2001) gave a much broader view on the subject by connoting that sustainable purchasing considers sustainability strategies in purchasing of inputs as compared to previous criteria, which focused on only cost, quality and delivery. This component or practice of SSCM allows organizations to demand key environmental information from suppliers, which also induces suppliers to be more oriented towards sustainable practices. This practice moves beyond just considering direct buying sources to include the green policies of indirect buying sources as well.

\subsubsection{Sustainable Supplier Partnerships}

Partnerships are seen as cross-organizational dependency relationships that aim to last over a specified period (Stuart, 1993). Li et al. (2006), defined supplier partnership as a long-term relationship that exists between an organization and its suppliers. Having highlighted these definitions, it is therefore right to say that sustainable supplier partnerships will go beyond just a mere relationship between an organization and its suppliers to consider the environmental and social contributions of these suppliers even before the said partnership can hold. According to Eltayab and Zailani (2009) and Hammer (2006), this means that organizations would move further to consider product contents, environmental management systems, certification and compliance auditing of direct suppliers 
and those who supply these direct suppliers before having partnerships to ascertain if suppliers are sustainability oriented.

\subsubsection{Green Information Sharing}

The essence of information sharing in a supply chain cannot be over-emphasized in this era of information technology. Information sharing means disseminating useful information for organizational stakeholders. Thus to assimilate sustainability into information sharing will be to seek and provide to supply chain stakeholder information related to environmental and social practices and contributions (Cooper et al., 1997). Several studies conducted in the discipline focused on the results of information sharing on supply chain unit's plans and revenues (Huang \& Wang, 2017). Findings suggested that information sharing is profitable for both upstream and downstream partners, thus, organizations should share quality information related to reducing harmful environmental impacts with all levels of units present in their supply chains (Huang \& Wang, 2017).

\subsection{Competitive Advantage}

Porter (1985) suggests that an organization that is able to generate a tenable position over rivals has a competitive advantage. This includes abilities that enable organizations to separate themselves from their rivals through efficient and effective strategic management decision making. Empirical literature on the subject over the years, identify price/cost, quality, delivery, and flexibility as core components of competitiveness (Tracey et al., 1999). Furthermore, Porter (1985) suggests that competitive advantage can be attained from cost advantage and differentiation advantage perspectives. According to Porter (1985), when organizations deliver same value to customers as competitors at reduced costs then they enjoy cost advantage. Furthermore, organizations that also enjoy benefits that are more than those of rival products are enjoying differentiation advantage. Competitive advantage tries to resolve some of the shortcomings of comparative advantage. The idea of competitive advantage suggests to both organizations and governments that policies should concentrate on creating high quality products that can sell at reasonable prices in the market. Porter (1985) signifies growth of productivity as the main aim of national strategies thereby highlighting that competitive advantage relies on the idea that inexpensive labour is ordinary and natural resources without skilled labour are not important for good economies. Competitive advantage is important for customers who are gratified and gain higher value in delivered products for higher income. Such customer satisfaction can be achieved by efficient organization of production and significant reduction in production costs (Ranko et al., 2008).

\subsection{Organizational Performance}

Performance measuring has gained an international ground in the sense that it entails measuring actual organizational outcomes with intended objectives. Organizational performance is a recurring topic to scholars especially across the domain of management research. Damanpour and Evan (1984) underscored the place of monitoring performance in effective performance management when they recommended that organizations and supply chain partners should not only agree on objectives but also on laid down actions that enable achievement of set of targets. This is true because actions or action plans, as well as monitoring mechanisms like frequent formal or informal reviews, coaching, and feedback are the catalysts that can determine success or failure in meeting objectives. According to March and Sutton (1997) the Strategic Management, Academy of Management and Administrative Science journals have 439 articles over a 3 -year period. The articles, which modelled performance as dependent variable, formed $23 \%$ of those articles. Many scholars investigated the widely accepted theory of performance measurement mostly from a dependent variable perspective (Gunasekaran et al., 2001; Sink \& Tuttle, 1990). Organizational performance has mostly been measured from marketing and financial perspectives (Almajali et al., 2012).

Recently, the evaluation of marketing performance has gained global consideration by firms. Gao (2010) defined marketing performance as a multidimensional procedure that involve three levels namely; effectiveness, efficiency and adaptability; the effectiveness and efficiency of an organization's marketing practices relate to market-oriented goals, such as revenues, growth, and market share. This indicates that market performance measures how well a company or product performs in the marketplace. Organizational performance is the evaluation of what has been achieved by a firm which shows positive conditions for a certain period of time. The aim of measuring what has been achieved is to derive vital information concerning the efficient and effective use of organizational resources (Almajali et al., 2012). Financial performance is defined as measuring a company's policies and operations in monetary terms. A firm's financial performance can be ascertained by looking at its return on assets and return on investment. We can also gauge its financial performance by measuring value added. From the above, this study adopted marketing and financial performance measures. 


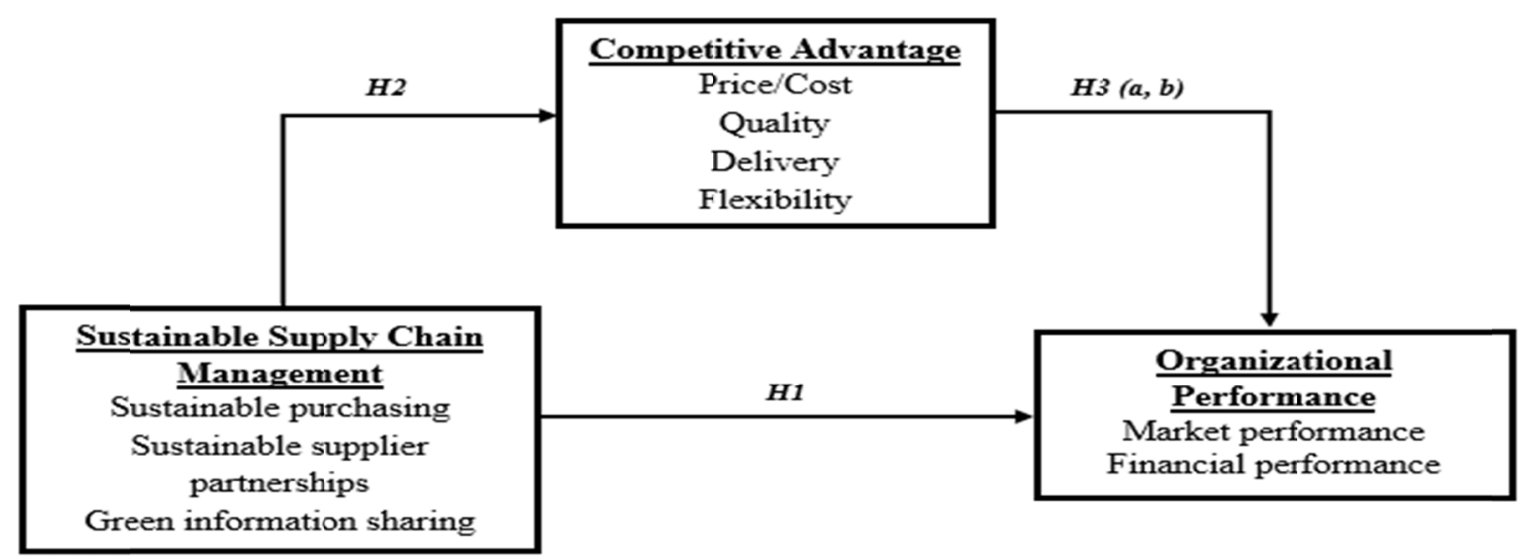

Figure 1. Research model

\subsection{Empirical Review and Hypotheses Development}

\subsubsection{The Link Between SSCM and Organizational Performance}

Extant studies conducted support that SCM practices positively affect firm performance (Zailani et al., 2012). Less studys have considered SSCM on organizational performance. According to Söderberg and Bengtsson (2010), organizations that use improved supply chain processes are most likely to attain positive relationship between supply chain performance and financial performance. Lee and Kim (2009) also indicated that supply chain integration is very crucial and vital to enhancing SSCM. According to Lee and Kim (2009), this leads to competitiveness from the SCM perspective. This view was supported by Lii and Kuo (2016) when in their study they agreed that there is the mediating role of supply chain integration on business performance. Carter and Rodgers (2008) suggests that organizations that consider environmental and social issues in making supply chain decisions will gain an upper hand in economic performance. This assertion can be attributed to current customers' awareness of the social and environmental responsibilities of organizations. Thus, most customers now consider these issues when making buying decisions. From supply chain perspective, both organizations and suppliers are now assessing the environmental and social orientations of their partners (Eltayab \& Zailani, 2009; Hammer, 2006). This can be because of the growing regulations from governments and international bodies on business activities negatively affecting the environment.

Firms that employ SSCM are likely to enjoy increase market and financial performances because they are able to reduce cost and entice environmentally conscious customers (Lii \& Kuo, 2016). Several scholars argue that organizations that efficiently and effectively implement and also manage the concepts of sustainable procurement, sustainable supplier partnerships, green information sharing, sustainable distribution, reverse logistics among others will improve both supply chain and organizational performance (Eltayab \& Zailani, 2009; Hammer, 2006; Huang \& Wang, 2017, Carter et al., 2009). From the above we develop the first hypothesis, which states:

\section{H1: SSCM has a positive influence on organizational performance.}

\subsubsection{The Link Between SSCM and Competitive Advantage}

Relating specifically to supply chain, some scholars argue that sustainable supply chain will bring about superior long-term performance through improved management of environmental risk and the acquisition and development of capabilities for continuous environmental improvement, leading to enhance corporate reputation (Alvarez \& Busenitz, 2001). The ability of an organization to secure environmentally conscious customers, will increase market share as well as give the organization an advantage with regards to reputation. According to the resourced-based view (RBV), the efficient and effective managing of scarce, important and inimitable resources (Barney \& Clark, 2007) grant an organization competitive advantage. However, by reason of the intense competition in current business environments, organizations are gradually noticing that resources available to them are not enough to maintain their competitive advantage. King (2007) defines competitive advantage as resources or competencies that are strenuous to copy and are valuable in helping organizations perform better than rivals. An organization can possess a good reputation from sustaining its supply chain partners as well as engage in sustainable purchasing and green information sharing with units in its supply chain. Such good reputation grows as an origin of strategic competitive advantage because of the ability to enter markets, increase market share through 
its market reach and bring about value for customers (Suh \& Amine, 2007). Good reputation is now a necessity for many competitive strategies which if well implemented attains and maintains competitive advantage (Flanagan $\&$ Shaughnessy, 2005).

Furthermore, it is established that environmental and socially proactive organizations develop unique information technology capabilities that enhance stakeholder integration, higher order learning among employees (Sharma, 2000), and continuous innovation to enhance strategic competitiveness (Banerjee, 2002). Additionally, there are intangible factors that suggest performance improvements when sustainability strategy is adopted. One intangible resource is the development of an environmental leadership reputation that will increase sales to environmentally conscientious customers. Corporate reputation is a principal origin of competitive advantage thus, an organization's ability to combine sustainability into supply chain practices will attract environmentally conscious customers, thus, earning that particular entity reputation which also eventually ends in competitive advantage if properly managed. Thus, a second hypothesis is suggested:

\section{H2: SSCM has a positive influence on competitive advantage.}

\subsubsection{The Link Between Competitive Advantage and Organizational Performance}

According to Ma (2000), competitive advantage and performance could have different patterns of relationship. Thus, examined their relationship using the following three categories: competitive advantage resulting in higher performance; competitive advantage which does not result in higher performance; and higher performance which is without competitive advantage. Existing literature connotes that customer gratification, reputation, and competitive advantage are positively linked to firm performance (Gupta \& Zeithaml, 2002). According to Gupta and Zeithaml (2002), customer gratification or satisfaction and reputation are key parts of competitive advantage. Awang and Jusoff (2009) also stipulated that corporate reputation greatly impacts on competitive advantage. Gupta and Zeithaml (2002) also supported the view by providing empirical evidence that organizational reputation positively influences competitive advantage by differentiating organizations from their rivals. According to past studies, customer satisfaction and corporate reputation positively influences each other and their relationship ultimately results in competitive advantage (Raduan et al., 2009). Raduan et al. (2009) specified that there are positive interactions between competitive advantage and organizational performance. Thus, competitive edge is proven to largely predict organizational performance. Raduan et al. (2009) showed an organization can achieve a competitive advantage when resources and competencies are rightly invested and utilised.

Competitive advantage depends on an organization's capacity to attract customers and build a good image for the organization and its products as well as improve customer satisfaction and perceived value (Diab, 2014). The above literature really captures the positive influence of competitive advantage on organizational performance, also highlighting how competitive advantage provides a firm with the abilities to outperform its rivals. In addition, literature suggests that in the service industry, competitive advantage enhances firm financial outcomes indirectly by improving market performance. Market performance refers to the firm's “ability to satisfy and retain customers by offering quality products and services..." and financial performance reflects the firm's profitability and market effect (Moorman \& Rust, 1999). Indicators mostly used to measure market performance consist customer satisfaction, product or service quality, customer retention, and customer loyalty, while costs, profitability and, sales revenue, market share are major indicators of financial performance (Moorman \& Rust, 1999). The above literature supports the third hypothesis, which states:

\section{H3a: Competitive advantage has a positive influence on organizational performance and}

\section{H3b: Competitive advantage plays an intermediary role between SSCM and organizational performance.}

\section{Methodology}

The quantitative approach was adopted in analysing data and making interpretations. The population in this study is made up of mostly management of logistics organisations operational in Ghana. In this study, 190 questionnaires were shared among managers of logistics organizations in Ghana. The questionnaire contains 9 questions for SSCM with 3 questions each trying to capture each core component specified in the literature, 6 questions for evaluating competitive advantage and 5 questions for capturing organizational performance. In order to enhance the strength of the model, items that had low factor loadings below the recommended threshold indicated in Table 1 were deleted from their respective constructs. This study employed partial least squares path structural equation modelling (PLS-SEM) method to estimate our structural model because PLS-SEM can achieve a high level of statistical power even with a relatively small sample size (Hair et al., 2013). It is also a structural equation modelling (SEM) technique that generates a vector of coefficients that relates a set of predictor variables to a set of dependent variables (Sosik et al. 2009). 
In addition, PLS handles both reflective and formative indicators. PLS insures against improper solutions by the removal of factor indeterminacy; this technique is robust in dealing with data noise and missing data as well as applies many parameters in a complex model with normal residual distributions; it also handles collinearity in the independent latent variables and has more statistical power than a maximum-likelihood covariance-based SEM method. Assessment of the model's performance was done by interrogating its convergent and discriminant validity, average variance extracted (AVE) and composite reliability. In measuring discriminant validity, we first considered factor loadings, went further to also look at Fornell-Lacker criterion, and finally considered the HTMT ratio. According to Table 1, the various construct reliability and validity measurement criteria should meet the recommended threshold indicated as follows;

Table 1. Measurement criteria thresholds

\begin{tabular}{ll}
\hline Measurement criteria & Recommended threshold \\
\cline { 2 - 2 } Factor loading (Hair et al., 1998) & $\geq 0.70$ \\
Composite reliability (Bagozzi \& Yi, 1988) & $\geq 0.60$ \\
Average Variance Extracted (Rodgers \& Pavlou, 2003) & $>0.50$ \\
Cronbach's Alpha (Henseler et al., 2009) & $\geq 0.70$ \\
HTMT Ratio (Hair et al., 1998) & $<0.85$ \\
\hline
\end{tabular}

Source: Adapted from Hair et al. (1998).

\section{Results/Findings}

This study employed partial least squares path structural equation modelling (PLS-SEM) method to estimate our structural model. According to Hair et al. (1998), the PLS-SEM method requires the assessment of the measurement model by checking the constructs validity and reliability. From Table 2, it is evident that the model achieves reliability since the Cronbach's Alpha and Composite Reliability were found to be within the range 0.818 to 0.865 and 0.876 to 0.907 respectively thereby suggesting that the constructs have high internal consistency and reliability. Again, convergent validity shows that a body of indicators should represents one underlying construct, which is also shown by their unidimensionality (Henseler et al., 2009). Rodgers and Pavlou (2003) suggested items which have low values should be removed and the model trimmed since trimming of the original measurement model improves the AVE and strengthens direct paths between the constructs as well as the entire model. From Table 2, the AVEs of the constructs were within the range 0.640 to 0.710 indicating that the constructs have convergent validity. The AVEs were all above the threshold of 0.5 as recommended by Rodgers and Pavlou (2003).

Table 2. Construct reliability and validity

\begin{tabular}{llll}
\hline Construct & Cronbach's Alpha & Composite Reliability & Average Variance Extracted (AVE) \\
\hline Competitive Advantage & 0.845 & 0.896 & 0.684 \\
Organizational Performance & 0.818 & 0.876 & 0.640 \\
Sustainable Supply Chain Management & 0.865 & 0.907 & 0.710 \\
\hline
\end{tabular}

Source: Field data (processed using SmartPLS).

\subsection{Discriminant Validity}

The Fornell-Lacker criterion indicated in Table 3, the factor loadings indicated in Table 4 and the HTMT ratio presented in Table 5 suggests that the constructs and model as a whole has discriminant validity and were all below their suggested thresholds. Table 3 indicates that the model has discriminant validity since all the square roots of the AVEs are larger than the correlations of the latent variables in the model.

Table 3. Fornell-larcker criterion

\begin{tabular}{llll}
\hline Construct & Competitive Advantage & Organizational Performance & Sustainable Supply Chain Management \\
\hline Competitive Advantage & 0.827 & & \\
Organizational Performance & 0.672 & 0.800 & \\
Sustainable Supply Chain Management & 0.630 & 0.685 & 0.842 \\
\hline
\end{tabular}

Source: Field data (processed using SmartPLS). 
Table 4 presents the factor loading of the constructs used in this study. All factor loadings were above 0.761 , which are well above the suggested value of 0.70 recommended by Hair et al. (1998).

Table 4. Factor loadings

\begin{tabular}{llll}
\hline Factors & Competitive Advantage & Organizational Performance & Sustainable Supply Chain Management \\
\hline CA1 & 0.769 & & \\
CA2 & 0.863 & & \\
CA3 & 0.873 & & \\
CA6 & 0.800 & 0.797 & \\
OP1 & & 0.799 & \\
OP2 & & 0.841 & \\
OP3 & & 0.761 & 0.827 \\
OP6 & & & 0.862 \\
SSCM1 & & 0.890 \\
SSCM2 & & & 0.787 \\
SSCM3 & & & \\
SSCM5 & & & \\
\hline
\end{tabular}

Source: Field data (processed using SmartPLS).

Table 5 presents the HTMT ratios of the constructs used in the model. Table 5 indicates that all constructs in the model were well below the value of 0.85 suggested by Henseler et al. (2015), since the highest value is 0.778 of competitive advantage.

Table 5. Heterotrait-Monotrait ratio (HTMT)

\begin{tabular}{llll}
\hline Construct & Competitive Advantage & Organizational Performance & Sustainable Supply Chain Management \\
\hline Competitive Advantage & & & \\
Organizational Performance & 0.778 & & \\
Sustainable Supply Chain Management & 0.710 & 0.727 & \\
\hline
\end{tabular}

Source: Field data (processed using SmartPLS).

\subsection{Structural Model}

The findings of Table 6 show R2, adjusted R2 and F2 values as well as path coefficients in the structural model. The R2 explains the variance of the endogenous variable predicted explained by the exogenous variable. The F2 explains the effect size and according to Cohen (1998) 0.02, 0.15, and 0.35 suggest small, medium and large effects respectively. Table 6 shows that competitive advantage and organizational performance have $\mathrm{R}$ square values of 0.397 and 0.565 . Additionally, the Adjusted R2 values were 0.394 and 0.561 respectively. This shows that SSCM and competitive advantage together predict 0.565 of the variances of organizational performance. SSCM individually predicts 0.397 of the variances of competitive advantage. The effect size, which is connoted by F2, shows that there are moderate effects of competitive advantage and SSCM of 0.220 and 0.262 respectively on organizational performance.

Table 6. Path estimations

\begin{tabular}{llll}
\hline & R Square & Adjusted R Square & F square \\
\hline Competitive Advantage & 0.397 & 0.394 & 0.220 \\
Organizational Performance & 0.565 & 0.561 & -- \\
Sustainable Supply Chain Management & -- & -- & 0.262 \\
\hline
\end{tabular}

\begin{tabular}{|c|c|c|c|c|c|}
\hline Path & $\begin{array}{l}\text { Beta } \\
\text { Coefficient }\end{array}$ & $\begin{array}{l}\text { Standard } \\
\text { Deviation }\end{array}$ & T Statistics & $\begin{array}{l}\mathrm{P} \\
\text { Values }\end{array}$ & $\begin{array}{l}\text { Hypothesis } \\
\text { Testing }\end{array}$ \\
\hline $\begin{array}{l}\text { Sustainable Supply Chain Management -> } \\
\text { Organizational Performance }\end{array}$ & 0.435 & 0.043 & 10.169 & 0.000 & H1: Supported \\
\hline $\begin{array}{l}\text { Sustainable Supply Chain Management -> } \\
\text { Competitive Advantage }\end{array}$ & 0.630 & 0.061 & 10.383 & 0.000 & H2: Supported \\
\hline $\begin{array}{l}\text { Competitive Advantage -> Organizational } \\
\text { Performance }\end{array}$ & 0.398 & 0.046 & 8.637 & 0.000 & H3a: Supported \\
\hline
\end{tabular}

Source: Field data (processed using SmartPLS). 


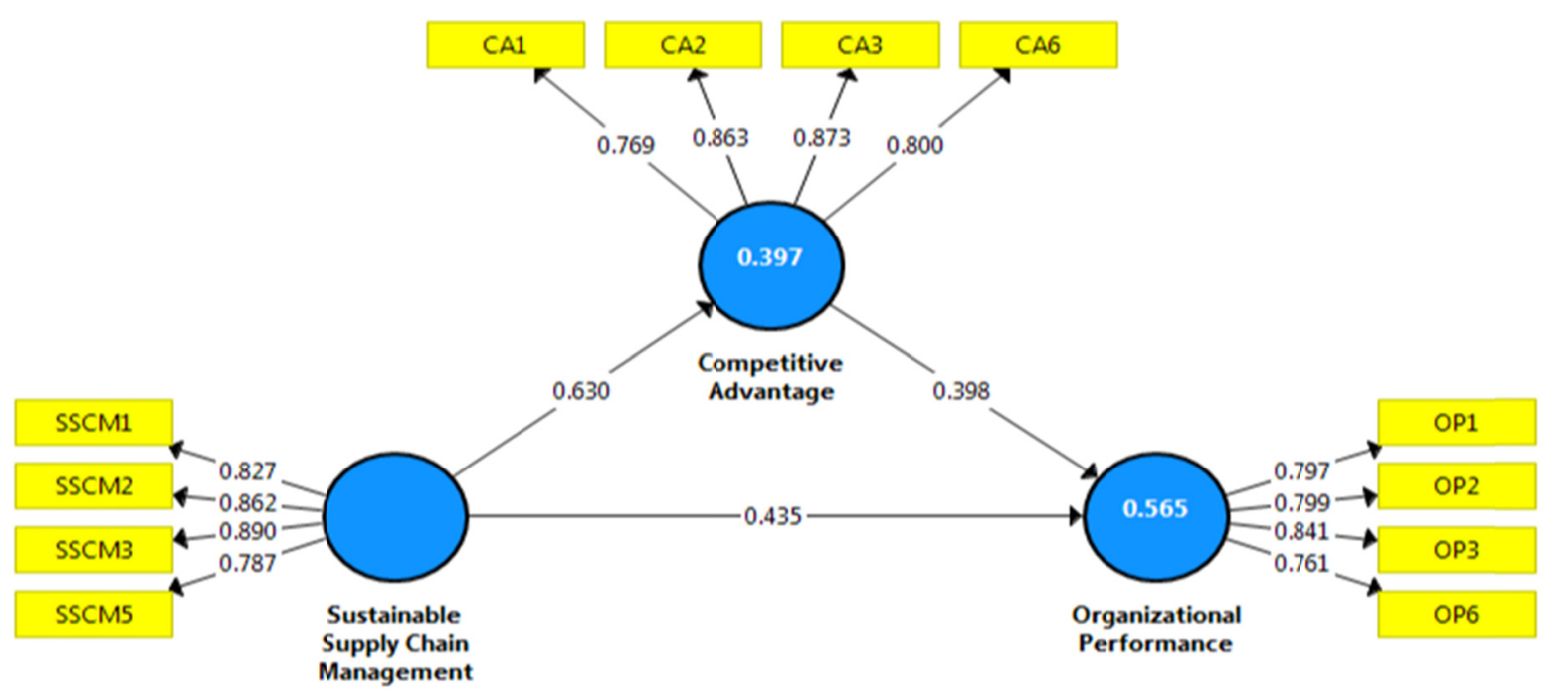

Figure 2. Structural model

From Table 6 and Figure 2, it is evident that all hypotheses in the study are supported. This means that hypothesis 1 , which states $\mathrm{H} 1$ : SSCM has a positive influence on organizational performance is supported ( $\beta=$ $0.435, \mathrm{p}=0.000$; Table 6 , Figure 2). This suggests that organizations should integrate sustainability into their supply chain decisions to enjoy improved performance (Eltayab \& Zailani, 2009; Hammer, 2006; Huang \& Wang, 2017). Furthermore, hypothesis 2, which also states H2: SSCM has a positive influence on competitive advantage is supported ( $\beta=0.630, p=0.000$; Table 6, Figure 2). Sharma (2000) and Banerjee (2002) support this finding by agreeing that environmental and socially proactive firms develop capabilities, which end up boosting competitiveness, that lead to enhanced corporate reputation and organizational performance. In addition, the hypothesis $3 \mathrm{a}$ that stated $\mathrm{H} 3 \mathrm{a}$ : Competitive advantage has a positive influence on organizational performance is supported $(\beta=0.398, p=0.000$; Table 6 , Figure 2$)$. The finding agrees that competitive advantage enhances firm financial performance indirectly through improving market performance (Diab, 2014; Raduan et al., 2009). Hypothesis $3 \mathrm{~b}$ which is the final hypothesis states that $\mathrm{H} 3 \mathrm{~b}$ : Competitive advantage plays an intermediary role between SSCM and organizational performance. Analysis of the data indicates that hypothesis $3 \mathrm{~b}$ is supported ( $\beta$ $=0.251, \mathrm{p}=0.000$; Table 7). Since both direct and indirect paths are both positive, it can be concluded there is complementary partial mediation. Thus, competitive advantage partially mediated the relationship between SSCM and organizational performance.

Table 7. Mediation (indirect effect)

\begin{tabular}{llllll}
\hline Path & Beta Coefficient & Standard Deviation & T Statistics & P Values & Hypothesis Testing \\
\hline $\begin{array}{l}\text { Sustainable Supply Chain Management -> } \\
\text { Competitive Advantage -> Organizational }\end{array}$ & 0.251 & 0.040 & 6.252 & 0.000 & H3b: \\
Performance & & & & & Supported \\
\hline
\end{tabular}

Source: Field data (processed using SmartPLS).

\section{Conclusions and Implications}

Although SSCM has proven to be a vital aspect of SCM which needs consideration and attention in this current industrial setting (Linton et al., 2007; Sarkis et al., 2011), diverse issues have arisen in trying to implement and manage this approach (Walker \& Jones, 2012). This study was conducted on organisations involved in logistics and known to be one of the sectors that pollute and consume enormous amount of resources. From this study, it is obvious that organizations that adopt business sustainability concepts into their supply chains are going to enjoy improved performance. This can be traced to reduced cost, customer attraction, and competitive advantage acquisition among others. Organizations that consider the triple bottom-line (economic, social and environmental orientations) according to this study will also experience the attainment of competitive advantage should SSCM approach and practices be effectively implemented and managed. Although this study recommends that firms fully accept SSCM, it is possible that organizations will continue undertaking SSCM initiatives in view of regulatory 
requirements coercing them to do so as well as their quest to satisfy key stakeholders (shareholders and customers) (Carter \& Rodgers, 2008). However, attention needs to be drawn to the fact that the initiation stages of sustainability is cost intensive. Despite the cost intensity, it is prudent to undertake SSCM in order to escape future legal restrictions, which may even drain more from organizational coffers. From this perspective, we recommend that both academics and practitioners should pay rapt attention to stakeholders' suggestions and should advise on governmental policies that will be environmentally and socially friendly since these lead to improved organizational performance.

\section{Limitations and Further Research}

To start with, this study is focused on sustainable supply chain practices of logistics organizations. This study can be modified and used in other sectors since now every organization is deemed to have a supply chain. Thus, data should be gathered and used to assess the effect of SSCM practices on performance of organizations in these other sectors. Although, this study considered a composite SSCM, it is also vital to evaluate the individual effects of these SSCM practices on performance as well as on competitive advantage. This study only considered three key SSCM practices namely sustainable purchasing, sustainable supplier partnership and green information sharing. It is vital to consider other constructs which incorporates other sustainable practices to get a whole view of SSCM. Further researches should also consider other moderating and mediating variables, which will contribute to existing literature concerning SSCM practices and organizational performance.

\section{References}

Ahi, P., \& Searcy, C. (2013). A comparative literature analysis of definitions for green and sustainable supply chain management. Journal of Cleaner Production, 52, 329-341. https://doi.org/10.1016/j.jclepro.2013.02.018

Almajali, A. Y., Alamro, S. A., \& Al-Soub, Y. Z. (2012). Factors affecting the financial performance of Jordanian insurance companies listed at Amman Stock Exchange. Journal of Management Research, 4(2), 266. https://doi.org/10.5296/jmr.v4i2.1482

Alvarez, S. A., \& Busenitz, L. W. (2001). The entrepreneurship of resource-based theory. Journal of Management, 27(6), 755-775. https://doi.org/10.1177/014920630102700609

Awang, Z. H., \& Jusoff, K. (2009). The effects of corporate reputation on the competitiveness of Malaysian telecommunication service providers. International Journal of Business and Management, 4(5), 173-178. https://doi.org/10.5539/ijbm.v4n5p173

Bagozzi, R. P., \& Yi, Y. (1988). On the evaluation of structural equation models. Journal of the Academy of Marketing Science, 16(1), 74-94. https://doi.org/10.1007/BF02723327

Banerjee, S. B. (2002). Corporate environmentalism: The construct and its measurement. Journal of Business Research, 55(3), 177-191. https://doi.org/10.1016/S0148-2963(00)00135-1

Barney, J. B., \& Clark, D. N. (2007). Resource-based theory: Creating and sustaining competitive advantage. Oxford University Press on Demand.

Beske, P., Land, A., \& Seuring, S. (2014). Sustainable supply chain management practices and dynamic capabilities in the food industry: A critical analysis of the literature. International Journal of Production Economics, 152, 131-143. https://doi.org/10.1016/j.ijpe.2013.12.026

Bhinge, R., Moser, R., Moser, E., Lanza, G., \& Dornfeld, D. (2015). Sustainability optimization for global supply chain decision-making. Procedia CIRP, 26, 323-328. https://doi.org/10.1016/j.procir.2014.07.105

Carter, C. R. (2005). Purchasing social responsibility and firm performance: the key mediating roles of organizational learning and supplier performance. International Journal of Physical Distribution \& Logistics Management, 35(3), 177-194. https://doi.org/10.1108/09600030510594567

Carter, C. R., Kale, R., \& Grimm, C. M. (2000). Environmental purchasing and firm performance: an empirical investigation. Transportation Research Part E: Logistics and Transportation Review, 36(3), 219-228. https://doi.org/10.1016/S1366-5545(99)00034-4

Carter, C. R., \& Liane Easton, P. (2011). Sustainable supply chain management: evolution and future directions. International Journal of Physical Distribution \& Logistics Management, 41(1), 46-62. https://doi.org/10.1108/09600031111101420 
Carter, C. R., \& Rogers, D. S. (2008). A framework of sustainable supply chain management: moving toward new theory. International Journal of Physical Distribution \& Logistics Management, 38(5), 360-387. https://doi.org/10.1108/09600030810882816

Cheng, J. H., Yeh, C. H., \& Tu, C. W. (2008). Trust and knowledge sharing in green supply chains. Supply Chain Management: An International Journal, 13(4), 283-295. https://doi.org/10.1108/13598540810882170

Cohen, J. (1969). Statistical power analysis for the behavioral sciences. New York: Academic Press.

Cooper, M. C., Lambert, D. M., \& Pagh, J. D. (1997). Supply chain management: more than a new name for logistics. The International Journal of Logistics Management, 8(1), 1-14. https://doi.org/10.1108/09574099710805556

Damanpour, F., \& Evan, W. M. (1984). Organizational innovation and performance: the problem of “organizational lag”. Administrative Science Quarterly, 392-409. https://doi.org/10.2307/2393031

Diab, S. M. (2014). Using the competitive dimensions to achieve competitive advantage: A study on Jordanian private hospitals. International Journal of Academic Research in Business and Social Sciences, 4(9), 138. https://doi.org/10.6007/IJARBSS/v4-i9/1136

Elkington, J. (1998). Partnerships from cannibals with forks: The triple bottom line of 21 st - century business. Environmental Quality Management, 8(1), 37-51. https://doi.org/10.1002/tqem.3310080106

Eltayeb, T. K., \& Zailani, S. (2009). Going green through green supply chain initiatives towards environmental sustainability. Operations and Supply Chain Management, 2(2), 93-110. https://doi.org/10.31387/oscm040019

Esfahbodi, A., Zhang, Y., \& Watson, G. (2016). Sustainable supply chain management in emerging economies: Trade-offs between environmental and cost performance. International Journal of Production Economics, 181, 350-366. https://doi.org/10.1016/j.ijpe.2016.02.013

Flanagan, D. J., \& O'shaughnessy, K. C. (2005). The effect of layoffs on firm reputation. Journal of Management, 31(3), 445-463. https://doi.org/10.1177/0149206304272186

Gao, J., \& Bansal, P. (2013). Instrumental and integrative logics in business sustainability. Journal of Business Ethics, 112(2), 241-255. https://doi.org/10.1007/s10551-012-1245-2

Gao, Y. (2010). Measuring marketing performance: a review and a framework. The Marketing Review, 10(1), 2540. https://doi.org/10.1362/146934710X488924

Gil, M. A., Jiménez, J. B., \& Lorente, J. C. (2001). An analysis of environmental management, organizational context and performance of Spanish hotels. Omega, 29(6), 457-471. https://doi.org/10.1016/S0305-0483(01)00033-0

Gunasekaran, A., Patel, C., \& McGaughey, R. E. (2004). A framework for supply chain performance measurement. International Journal of Production Economics, 87(3), 333-347. https://doi.org/10.1016/j.ijpe.2003.08.003

Gupta, S., \& Zeithaml, V. (2006). Customer metrics and their impact on financial performance. Marketing Science, 25(6), 718-739. https://doi.org/10.1287/mksc. 1060.0221

Hair, J. F., Ringle, C. M., \& Sarstedt, M. (2013). Partial least squares structural equation modeling: Rigorous applications, better results and higher acceptance. Long Range Planning, 46(1-2), 1-12. https://doi.org/10.1016/j.lrp.2013.01.001

Hammer, A. (2006). Enabling Successful Supply Chain Management-Coordination, Collaboration, and Integration for Competitive Advantage. Universitätsbibliothek.

Henseler, J., Ringle, C. M., \& Sinkovics, R. R. (2009). The use of partial least squares path modeling in international marketing. In R. S. Rudolf \& N. G. Pervez (Eds.), New challenges to international marketing (pp. 277-319). Emerald Group Publishing Limited. https://doi.org/10.1108/S1474-7979(2009)0000020014

Holmberg, S. (2000). A systems perspective on supply chain measurements. International Journal of Physical Distribution \& Logistics Management, 30(10), 847-868. https://doi.org/10.1108/09600030010351246

Huang, Y., \& Wang, Z. (2017). Information sharing in a closed-loop supply chain with technology licensing. International Journal of Production Economics, 191, 113-127. https://doi.org/10.1016/j.jpe.2017.06.008

King, A. W. (2007). Disentangling interfirm and intrafirm causal ambiguity: A conceptual model of causal ambiguity and sustainable competitive advantage. Academy of Management Review, 32(1), 156-178. https://doi.org/10.5465/amr.2007.23464002 
Lambert, D. M., Cooper, M. C., \& Pagh, J. D. (1998). Supply chain management: implementation issues and research opportunities. The International Journal of Logistics Management, 9(2), 1-20. https://doi.org/10.1108/09574099810805807

Lee, K. H., \& Kim, J. W. (2009). Current status of CSR in the realm of supply management: the case of the Korean electronics industry. Supply Chain Management: An International Journal, 14(2), 138-148. https://doi.org/10.1108/13598540910942000

Lii, P., \& Kuo, F. I. (2016). Innovation-oriented supply chain integration for combined competitiveness and firm performance. International Journal of Production Economics, 174, 142-155. https://doi.org/10.1016/j.jpe.2016.01.018

Linton, J. D., Klassen, R., \& Jayaraman, V. (2007). Sustainable supply chains: An introduction. Journal of Operations Management, 25(6), 1075-1082. https://doi.org/10.1016/j.jom.2007.01.012

Li, S., Ragu-Nathan, B., Ragu-Nathan, T. S., \& Rao, S. S. (2006). The impact of supply chain management practices on competitive advantage and organizational performance. Omega, 34(2), 107-124. https://doi.org/10.1016/j.omega.2004.08.002

Ma, H. (2000). Competitive advantage and firm performance. Competitiveness Review: An International Business Journal, 10(2), 15-32. https://doi.org/10.1108/eb046396

March, J. G., \& Sutton, R. I. (1997). Crossroads — organizational performance as a dependent variable. Organization Science, 8(6), 698-706. https://doi.org/10.1287/orsc.8.6.698

Mentzer, J. T., DeWitt, W., Keebler, J. S., Min, S., Nix, N. W., Smith, C. D., \& Zacharia, Z. G. (2001). Defining supply chain management. Journal of Business Logistics, 22(2), 1-25. https://doi.org/10.1002/j.2158-1592.2001.tb00001.x

Miles, M. P., Covin, J. G., \& Heeley, M. B. (2000). The relationship between environmental dynamism and small firm structure, strategy, and performance. Journal of Marketing Theory and Practice, 8(2), 63-78. https://doi.org/10.1080/10696679.2000.11501869

Moorman, C., \& Rust, R. T. (1999). The role of marketing. Journal of Marketing, 63(4_supp11), 180-197. https://doi.org/10.1177/00222429990634s117

Pagell, M., \& Gobeli, D. (2009). How plant managers' experiences and attitudes toward sustainability relate to operational performance. Production and Operations Management, 18(3), 278-299. https://doi.org/10.1111/j.1937-5956.2009.01050.x

Pagell, M., \& Wu, Z. (2009). Building a more complete theory of sustainable supply chain management using case studies of 10 exemplars. Journal of Supply Chain Management, 45(2), 37-56. https://doi.org/10.1111/j.1745-493X.2009.03162.x

Porter, M. E. (1985). Competitve advantage. Free Press (The Free Press).

Raduan, C. R., Jegak, U., Haslinda, A., \& Alimin, I. I. (2009). Management, strategic management theories and the linkage with organizational competitive advantage from the resource-based view. European Journal of Social Sciences, 11(3), 402-418.

Ranko, S., Berislav, B., \& Antun, S. (2008). Document management system as source of competitive advantage. New Ways in Manufacturing Engineering.

Robinson, D. R., \& Wilcox, S. (2008). The greening of the supply chain. Logistics Management, 47(10).

Rodgers, W., \& Pavlou, P. (2003). Developing a predictive model: a comparative study of the partial least squares vs. maximum likelihood techniques. Riverside: Graduate School of Management, University of California, Riverside.

Roslender, R., \& Hart, S. J. (2002). Integrating management accounting and marketing in the pursuit of competitive advantage: the case for strategic management accounting. Critical Perspectives on Accounting, 13(2), 255-277. https://doi.org/10.1006/cpac.2001.0477

Sarkis, J., Zhu, Q., \& Lai, K. H. (2011). An organizational theoretic review of green supply chain management literature. International Journal of Production Economics, 130(1), 1-15. https://doi.org/10.1016/j.ijpe.2010.11.010 
Seuring, S., \& Müller, M. (2008). From a literature review to a conceptual framework for sustainable supply chain management. Journal of Cleaner Production, 16(15), 1699-1710. https://doi.org/10.1016/j.jclepro.2008.04.020

Sharma, S. (2000). Managerial interpretations and organizational context as predictors of corporate choice of environmental strategy. Academy of Management Journal, 43(4), 681-697. https://doi.org/10.2307/1556361

Sharma, S., \& Vredenburg, H. (1998). Proactive corporate environmental strategy and the development of competitively valuable organizational capabilities. Strategic Management Journal, 19(8), 729-753. https://doi.org/10.1002/(SICI)1097-0266(199808)19:8<729::AID-SMJ967>3.0.CO;2-4

Sink, D. S., \& Tuttle, T. C. (1990). The performance management question in the organization of the future. Industrial Management, 32(1), 4-12.

Söderberg, L., \& Bengtsson, L. (2010). Supply chain management maturity and performance in SMEs. Operations Management Research, 3(1-2), 90-97. https://doi.org/10.1007/s12063-010-0030-6

Sosik, J. J., Kahai, S. S., \& Piovoso, M. J. (2009). Silver bullet or voodoo statistics? A primer for using the partial least squares data analytic technique in group and organization research. Group \& Organization Management, 34(1), 5-36. https://doi.org/10.1177/1059601108329198

Stock, J. R., \& Boyer, S. L. (2009). Developing a consensus definition of supply chain management: a qualitative study. International Journal of Physical Distribution \& Logistics Management, 39(8), 690-711. https://doi.org/10.1108/09600030910996323

Stuart, F. I. (1993). Supplier partnerships: influencing factors and strategic benefits. International Journal of Purchasing and Materials Management, 29(3), 21-29. https://doi.org/10.1111/j.1745-493X.1993.tb00015.x

Suh, T., \& Amine, L. S. (2007). Defining and managing reputational capital in global markets. Journal of Marketing Theory and Practice, 15(3), 205-217. https://doi.org/10.2753/MTP1069-6679150302

Svensson, G. (2007). Aspects of sustainable supply chain management (SSCM): conceptual framework and empirical example. Supply Chain Management: An International Journal, 12(4), 262-266. https://doi.org/10.1108/13598540710759781

Tracey, M., Vonderembse, M. A., \& Lim, J. S. (1999). Manufacturing technology and strategy formulation: keys to enhancing competitiveness and improving performance. Journal of Operations Management, 17(4), 411428. https://doi.org/10.1016/S0272-6963(98)00045-X

Walker, H., \& Jones, N. (2012). Sustainable supply chain management across the UK private sector. Supply Chain Management: An International Journal, 17(1), 15-28. https://doi.org/10.1108/13598541211212177

Wang, Q., Dai, H. N., \& Wang, H. (2017). A smart MCDM framework to evaluate the impact of air pollution on city sustainability: a case study from China. Sustainability, 9(6), 911. https://doi.org/10.3390/su9060911

WCED, S. W. S. (1987). World commission on environment and development. Our common future.

Weeratunge, R. D., \& Herath, R. (2017). The Dimensions of Green Supply Chain Management Practices. In Proceedings of the 3rd World Conference on Supply Chain Management (Vol. 2, pp. 123-132). https://doi.org/10.17501/wcosm.2017.2111

Yamin, S. G., \& Mavondo, T (1999). Relationship between generic strategy, competitive advantage and firm $\begin{array}{llll}\text { performance: an empirical } & \text { analysis. Technovation, }\end{array}$ https://doi.org/10.1016/S0166-4972(99)00024-3

Zailani, S., Jeyaraman, K., Vengadasan, G., \& Premkumar, R. (2012). Sustainable supply chain management (SSCM) in Malaysia: A survey. International Journal of Production Economics, 140(1), 330-340. https://doi.org/10.1016/j.ijpe.2012.02.008

Zsidisin, G. A., \& Siferd, S. P. (2001). Environmental purchasing: a framework for theory development. European Journal of Purchasing \& Supply Management, 7(1), 61-73. https://doi.org/10.1016/S0969-7012(00)00007-1

\section{Copyrights}

Copyright for this article is retained by the author, with first publication rights granted to the journal.

This is an open-access article distributed under the terms and conditions of the Creative Commons Attribution license (http://creativecommons.org/licenses/by/4.0/). 